\title{
Accidental hydroxyurea over-dosage in a child with sickle cell anemia: an African experience
}

\author{
Uche Nnebe-Agumadu ${ }^{1}$, Innocent Adebayo ${ }^{2}$, Obiageli Nnodu ${ }^{3}$, and Adekunle Adekile ${ }^{4}$ \\ ${ }^{1}$ University of Abuja \\ ${ }^{2}$ University of Abuja Teaching Hospital \\ ${ }^{3}$ University of Abuja College of Health Sciences \\ ${ }^{4}$ Kuwait University
}

May 20, 2020

\begin{abstract}
We report a case of a 34-month-old girl who has been followed up for 12 months after ingesting $105 \mathrm{mg} / \mathrm{kg}$ of hydroxyurea (HU) and showed only transient mild bone marrow suppression. With anticipated increase in HU use among children with SCD in sub-Saharan Africa, the possibility of accidental ingestion should be envisaged and appropriate user-education and management guidelines established. Toxicity from accidental HU overdosage is generally mild and transient and should not constitute a barrier to its use in Nigerian children with SCD.
\end{abstract}

\section{INTRODUCTION}

Several studies have documented the use of hydroxyurea (HU) as an effective, safe and affordable oral drug for SCD ${ }^{1,2}$ but utilization remains poor in Nigeria ${ }^{3,4}$ and most parts of sub-Saharan Africa ${ }^{5}$ partly because of safety concerns. As a drug that selectively suppresses hematopoiesis in a situation where enhanced erythropoiesis is desired ${ }^{6}$, questions about its benefits and risks will always arise. Children who have been followed up for over 15 years have shown no significant toxicity in terms of growth and sexual development ${ }^{7}$. Studies from Nigeria ${ }^{8,9}$ and Africa including the NOHARM and REACH studies ${ }^{10-12}$, are increasingly strengthening the general acceptance of $\mathrm{HU}$ as a safe intervention in children with SCD in Africa thus dispelling fears about altered response in African children because of host and environmental factors. As efforts are made to improve its uptake in Nigeria, cases of accidental ingestion may arise, which could further fuel the fear most families have about HU toxicity. We, hereby, report this case of accidental ingestion of a large dose of $\mathrm{HU}$ to further strengthen the safety profile of $\mathrm{HU}$ and to advocate for increased use of this cheap disease-modifying agent in Nigerian children with SCD.

\section{Case Report}

We present a 34-month-old female with sickle cell anemia (SCA HbSS) who was diagnosed at 15 months of age. She was one of the first set of patients to use HU in the Pediatric Hematology Unit of the University of Abuja Teaching Hospital from January 2017 . The unit offers comprehensive care to patients with SCD, that includes structured health education in addition to prophylaxis for malaria and pneumococcal infections. She had all childhood immunizations according to the National Program on Immunization, including pneumococcal and meningococcal vaccines. Following parental consent, she was started on HU at a daily dose of $15 \mathrm{mg} / \mathrm{kg}$ (187mg daily) for frequent, recurrent severe bone pain crises. HU was compounded by the hospital pharmacy, using vitamin $\mathrm{C}$ syrup and was renewable fortnightly. Within the first year, there was a dose escalation to $20 \mathrm{mg} / \mathrm{kg}$ with good hematologic response. Her parents were satisfied with the therapy and reported reduction in acute painful episodes and improved general wellbeing of the patient. 
At 13 months of HU therapy, her parents called the managing team to report accidental ingestion of an overdose of HU. She was said to have ingested the entire contents of the medication in the container. The child was stable at presentation to the emergency room eighteen hours after drug ingestion. She had ingested about $105 \mathrm{mg}$ per kilogram body weight of $\mathrm{HU}$, which was equivalent to 5 times her regular daily dose. Because she presented late, vomiting was not induced, and activated charcoal was not administered. HU serum levels could not be determined.

At presentation, she had mild myelosuppression as her total white blood cell and absolute neutrophil counts dropped but values were back to pre-overdose levels about 21 days later. Hemoglobin concentration remained fairly constant after overdose while there was a steady increase in mean corpuscular volume. Apart from a transient rise in serum creatinine 18 hours post ingestion, the transaminases and creatinine were down to pre-ingestion levels within 3 weeks of $\mathrm{HU}$ overdose. Patient is currently doing well. Hematologic indices one year post overdose, remain stable but serum creatinine and alanine transaminase show mild increase (Table 1). Patient is still being followed up.

\section{DISCUSSION}

We are not aware of any previous report of accidental HU overdose of several times the regular dose in a child with sickle cell anaemia from Africa. Contrary to the common perception of toxicity associated with $\mathrm{HU}$, our patient did not show significant myelosuppression or renal and hepatic dysfunction and was able to resume HU after a short time of suspension of therapy. $\mathrm{HU}$ is a myelosuppressive compound and is generally expected that all patients taking it will have at least one episode of myelosuppression with white cell and/or platelet counts falling into a low range requiring dose adjustment or outright discontinuation of therapy 13,14. Our patient had a good response to $\mathrm{HU}$ with anticipated degree of myelosuppression within the first 12 months until this was worsened by accidental overdosage.

$\mathrm{HU}$ is very well absorbed orally with a half-life that varies with age and renal function but on the average is about 2-4 hours after ingestion of a dose of $20 \mathrm{mg} / \mathrm{kg}{ }^{15,16}$. Our patient was on $20 \mathrm{mg} / \mathrm{kg}$ before the accidental overdosage occurred. We had no means of measuring her serum levels of HU but the mild myelosuppression observed may be explained by rapid renal clearance such that the deranged laboratory indices had peaked by 24 hours post ingestion. Children with diminished glomerular filtration rates might be expected to show more severe toxicity ${ }^{17}$.

So far, only three cases of hydroxyurea overdose have been reported in the literature. One massive accidental overdose of a two-year-old girl enrolled in BABY HUG at age 11 months who ingested 35 times her intended daily dose of $17.5 \mathrm{mg} / \mathrm{kg}$ but had just mild and transient myelosuppression. She had full bone marrow recovery in two weeks ${ }^{18}$. Our patient also had full recovery of bone marrow function in less than three weeks. The other two were modest, 15 and 2.5 times the prescribed dosage, reported in the HUSOFT trial $^{18,19}$. These also resulted in only mild and transient neutropenia.

Although there are limited readily-available modalities of management of HU toxicity, a few recommendations have been suggested. One of such recommendations by manufacturers is gastric lavage if patient presents within 90 minutes of ingestion, followed by supportive care and close monitoring of hemopoietic system. Ipecac and activated charcoal are handy remedies but are unsuitable for home use especially for very young patients ${ }^{20}$. Our patient had none of these interventions because of late presentation and still did well on active observation and temporary suspension of therapy.

\section{CONCLUSION}

Accidental over-dosage remains a cause of concern with anticipated increase in the use of HU, especially the sweet compounded formulations. This calls for parental education on proper drug storage and use of child-safety caps. Limiting prescriptions of compounded formulations to a two-week supply will reduce the likelihood of any substantial large overdose. Temporary cessation of therapy, close observation and monitoring for myelosuppression for about four weeks should be adequate intervention for most instances of overdosage in young children with SCA. 
Declaration of interests: None

\section{References}

1. Lobe C, Hankins JS, Moura P, Pinto JC. Hydroxyurea therapy reduces mortality among children with sickle cell disease.Blood.2010;116:843-5.

2.Thomas R, Dulman R, Lewis A, Notarangelo B, Yang E. Prospective longitudinal follow-up of children with sickle cell disease treated with hydroxyurea since infancy. Pediatr Blood Cancer.2019; 66: 27816.

3. Galadanci N, Wudil BJ, Balogun TM, Ogunrinde GO, Akinsulie A, Hasan-hanga F et al. Current sickle cell disease management practices in Nigeria. Int Health. 2014; 6:23-8.

4. Ojewumi OO, Adeyemo TA, Ayinde OC, Iwalokun B, Adekile A. Current perspectives of sickle cell disease in Nigeria: changing narratives. Expert Rev Hematol. 2020;12:609-20.

5. Dubert M, Elion J, Tolo A, Diallo DA, Diop S, Diagne I et al. Degree of anemia, indirect markers of hemodialysis, and vascular complications of sickle cell disease in Africa. Blood.2017; 130: 2215-23.

6. Green NS, Barral S. Emerging science of hydroxyurea therapy for pediatric sickle cell disease. Pediatr Res. 2014; 75:196-204.

7. Hankins JS, Aygun B, Nottage K, Thornburg C, Smeltzer MP, Ware RE et al. From infancy to adolescence: fifteen years of continuous treatment with hydroxyurea in sickle cell anemia. Med(Baltimore) 2014; 93:215.

8.Akinsete AM. Experience with hydroxycarbamide use, indications, adverse effects and clinical course at a tertiary hospital in Lagos. Big Qtrly J Hosp Med. 2018; 28: 26-30.

9. Ofokunrin AOD, Adekoba KU, Oguche S, Okpe ES, Sagay AS. Efficacy and safety of hydroxyurea in the treatment of sickle cell disease in children in Jos, North central Nigeria. Blood. 2018;132:1081.

10. Pooja RO, Ndugwu CM, Latham TS, Lane A, Hume HA, Kasirye P et al. Novel use of hydroxyurea in an African region with malaria(NOHARM): a randomized controlled trial. Blood. 2017; 130: $2585-93$.

11. Tshilolo L, Tomlinson G, William's TN, Santos B, Olupot- Olupot P, Lanre A, at al. Hydroxyurea for children with sickle cell anemia in sub- Sahara Africa (REACH). N Engl J Med. 2019;380: 121-31.

12. Luzzatto L, Makani J. Hydroxyurea- An essential medicine for sickle cell disease in Africa.N Engl J Med. 2019; 380: 187-9

13. Russell E, Ware MD. Hydroxycarbamide: clinical aspects. C R Biol. 2013; 336: 177-82.

14. Platt OS. Hydroxyurea for the treatment of sickle cell anemia. N Engl J Med.

2008; 358: 1362-9.

15. Ware RE, Despotovic JM, Mortier NA, Flanagan JM, He J, Smeltzer MP et al. pharmacokinetics, pharmacodynamics, and pharmacokinetics of hydroxyurea treatment for children with sickle cell anemia. Blood. 2011; 118:4985-91.

16. Gwilt PR. Pharmacokinetics and pharmacodynamics of hydroxyurea. Clin Pharmacokinet. 1998;34:34758.

17. Yan JH, Ataga K, Kaul S, Olson JS, Grasela DM, Gothelf S, Kutlar A, Orringer E. The influence of renal function on hydroxyurea pharmacokinetics in adults with sickle cell disease. J Clin Pharmacol. 2005;45:43445.

18. Scott TM, Kathy R, Jin H, Jonathan F, Billie JF, Zora RR, Winfred CN. Massive accidental overdose of hydroxyurea in a young child with sickle cell anemia. Pediatr Blood Cancer. 2012; 59: 170-2.

19. Wang WC, Wynn LW, Roger's ZR, Scott JP, Lane PA, Ware RE. A two- year pilot trial of hydroxyurea in very young children with sickle cell anemia. J Pediatr. 2001; 139: 790- 6. 
20. American Academy of Pediatrics Committee on injury, violence and poison treatment in the home. Pediatr. 2003; 112:1182-5.

\section{Hosted file}

HU overdosage_Table1.docx available at https://authorea.com/users/324442/articles/452633accidental-hydroxyurea-over-dosage-in-a-child-with-sickle-cell-anemia-an-africanexperience 